\title{
Indonesian Language Textbook based on Educational Unit Level Curriculum for Senior High School Students
}

\author{
A Study on Ecological Literacy Perspective
}

\author{
$1^{\text {st }}$ Sarwiji Suwandi \\ Faculty of Teacher Training and \\ Education: Indonesian Language \\ Education \\ Sebelas Maret University \\ Surakarta, Indonesia \\ sarwijiswan@staff.uns.ac.id
}

\author{
$2^{\text {nd }}$ Ahmad Yunus \\ Faculty of Agriculture: \\ Agrotechnology \\ Sebelas Maret University \\ Surakarta, Indonesia \\ yunus@staff.uns.ac.id
}

\author{
$3^{\text {rd }}$ Hasan Zainnuri \\ Faculty of Teacher Training and \\ Education: English Language \\ Education \\ Sebelas Maret University \\ Surakarta, Indonesia \\ hasan_zainnuri@staff.uns.ac.id
}

\begin{abstract}
Indonesia has experienced a number of disasters recently causing enormous losses to the community, both materially as well as spiritually. The contributing factors to this incident include the low level of public environmental awareness. For this reason, the efforts to educate people and students are necessary. One of the important elements of this effort is the availability of books concerning with ecoliteracy. This study aims at explaining the ecological literacy values in Indonesian language textbook for senior high school students based on Educational Unit Level Curriculum. In this study, there are three books analyzed using document analysis as data resources. To examine the ecological literacy values both descriptive and distributive, content analysis is used as the main method. Content analysis can be either quantitative or qualitative, or both. The study used a mixed approach to analyze both qualitative and quantitative data in a single study with "the purpose of gaining insight and extensive and profound proof". Based on the analysis result, the ecological literacy values include (1) ecological knowledge $(63.5 \%)$, (2) affective tendency $(11.7 \%)$, (3) behavior $(11.7 \%)$, and (4) cognitive skills $(12.9 \%)$. It can be concluded that the ecological literacy value is still dominated by ecological knowledge.
\end{abstract}

Keywords-ecological literacy, textbooks, Indonesian language, Educational Unit Level Curriculum

\section{INTRODUCTION}

This Environmental problems have become an integral part of today's world problems. Five decades ago people rarely thought that the issue of saving the environment would be an issue of equal importance to other major world issues, such as the problem of poverty and efforts to realize the world peace [1]. In addition, several decades ago economic development was believed to be an important effort to reduce millions of poor people from poverty. However, most people forget that economic development transcending the limits causes complex environmental problems.

Natural resources scattered on the surface of the earth are provided for the benefit of mankind. However, population growth and uncontrolled patterns of economic growth have caused damage to natural resources and increased environmental pollution. The environment becomes collapsed and develops into a global crisis so that policies are needed to support human life in a sustainable manner [2]. Conservation and sustainable development are important policies for efforts to save the use of natural resources and improve the environment [1].

Environmental problems are now faced by many countries, including Indonesia. Indonesia has experienced a number of disasters recently causing enormous losses to the community, both materially as well as spiritually. The contributing factors to this incident include the low level of public environmental awareness. For this reason, the efforts to educate people and students are necessary. Environmental education is an important factor to minimize environmental damage.

Environmental education is believed to be one alternative solution that is effective and efficient in improving public knowledge and understanding of the preservation of environmental functions. Environmental education in Indonesia has not yet had a positive influence on changes in public awareness and behavior in taking valuable actions or in favor of the environment and society.

Awareness improvement about environmental conservation can be done through language learning because it can communicate and internalize knowledge and values. The most important thing in learning language is to use that language [3]. Language skills realized in the form of language use can be divided into two, namely receptive and productive skills [4]. 
Books as a medium of ecological literacy have a strategic role. The importance of books in learning cannot be denied. The textbook should be seen as a source in achieving the learning objectives that have been set. Textbooks have two roles in language learning and can function as (1) sources for oral or written presentation material; (2) sources of activity for students' communicative practices and interactions; (3) reference sources for students regarding linguistic aspects (grammar, vocabulary, pronunciation, etc.); (4) sources of stimuli and ideas for classroom language activities; (5) syllabus (in the book there is a predetermined learning goal) [5].

Books are also seen as important as a medium for ecological literacy for students to realize a sustainable society. A sustainable society builds and arranges their life together by relying on awareness on the importance of living environment. This awareness is known as ecoliteracy [6]. Ecoliteracy is a term to describe humans who have reached a high level of awareness about the importance of the environment. Another term used for the same meaning is ecological literacy. Both terms are used interchangeably because ecoliteracy is the abbreviation of ecological literacy.

The environmental literacy is essentially the capacity to perceive and interpret the relative health of environmental systems and take appropriate action actions, restore, or improve the health of those systems [7]. Ecological literacy is divided into four components, namely (1) knowledge which includes ecological knowledge, social-politic knowledge, and knowledge of environmental issue; (2) affective tendency; (3) behavior which includes additional determinants of environmentally responsible behavior, environmentally responsible behavior, and (4) cognitive skills [7]. In another framework example, there are the same four clusters of environmental literacy components: cognitive dimensions (knowledge and skill), affective dimensions, additional determinants of environmentally responsible behavior, and personal and/or group involvement in environmentally responsible behavior [9].

This study aims to study the value of ecological literacy values comprehensively,contained in Indonesian textbooks for high schools in order to implement the education unit level curriculum and provide suggestions for improvement of the textbook. Research problems include: (1) What are the ecological literacy values contained in the textbook? (2) What is the distribution of these values? (3) What are the advantages and disadvantages of the textbook, especially related to the values of ecological literacy.

Some of the studies that have been developed in the order of the contribution of Eco-Schools Program on the development of student's environmental literacy. A study compared environmental literacy between Eco-Schools and Ordinary Schools of Slovenia and concluded that the knowledge is the only component that showed a statistical significant improvement [8]. In Iceland, a comparison of environmental knowledge, attitude and actions between students from Green-Flag schools and traditional schools showing that Eco-School students were more aware of environmental issues but did not have a significant better environmental knowledge or attitude. However, this study showed that, despite the Eco-Schools Program having little effect on students' environmental knowledge and attitude, it could encourage, through situational factors, directly linked to facilities available in the school, namely recycling containers [9]. In Flanders (Belgium), it is found that Eco-Schools Program mainly influenced their students' environmental knowledge, but had no positive effects on environmental attitude and behavior [8]. Another research on private schools of Turkey, it is found a significant increase in students from eco-schools, not just in knowledge but also in environmental attitude [10].

\section{METHODS}

First, Document analysis method as one of the qualitative studies is applied to study the content of ecological literacy in textbooks, both descriptive and distributive. The source of this research data are three Indonesian textbooks used for students of class XI and XII of senior high school in Central Java in the academic year of 2017/2018 implementing Education Unit Level Curriculum. These three books are entitled (1) Bahasa dan Sastra Indonesia untuk SMA, written by Sri Utami, Sugiharti, Suroto, and Alexander Sosa, published by PT. Galaxy Puspa Mega consists of 12 chapters with $8+174$ pages thick; (2) Cerdas Berbahasa Indonesia, written by Engkos Kosasih, published by Erlangga consisting of 8 chapters with 6+218 pages thick; and (3) Terampil Berbahasa Indonesia, written by Gunawan Budi Santoso, Wendi Widya RD, and Uti Darmawati, published by the Ministry of National Education, consisting of 11 chapters with $6+170$ pages thick.

In this study, content analysis was used to interpret data obtained through document review. Content analysis can be either quantitative or qualitative, or both [11]. This study used a mixed approach to analyze both qualitative and quantitative data in a single study with "the purpose of gaining insight and extensive and profound proof" [12]. In this study, we chose concurrent triangulation designs. In this design, quantitative and qualitative data are collected and analyzed at the same time, and integration usually occurs at the data interpretation stage. This design is useful for confirming, validating, and corroborating research findings [13]. The main activity carried out in content analysis is to collect similar data within the framework of specific ideas and themes and interpret them by well organizing so that the reader can understand them. In this study, ecological literacy is defined as the main category. Meanwhile, subcategories include components (1) knowledge that includes ecological knowledge, social-politic knowledge, and knowledge of environmental issues; (2) affective tendency, (3) behavior that includes additional determinants of environmentally responsible behavior and environmentally responsible behavior; and (4) cognitive skills that shape ecological literacy and are supported by literature.

The elements studied from the textbook include introduction to chapters, texts, assignments, exercises, questions, and summaries. The unit of analysis of this study is sentence or paragraph. To ensure the reliability of this study, 
all texts are read by two different researchers separately and then compared to determine the suitability. If there is a discrepancy, it needs the opinion of an expert.

\section{RESULT AND DISCUSSION}

The content of ecological literacy in all three Indonesian textbooks used for high school students can be seen in Table 1 below.

TABLE I. FREQUENCY DISTRIBUTION AND PERCENTAGE OF ECOLOGICAL LITERACY ON INDONESIAN TEXTBOOKS FOR SENIOR HIGH SCHOOL

\begin{tabular}{|c|c|c|c|c|c|c|}
\hline \multicolumn{2}{|c|}{$\begin{array}{c}\text { Indonesian Language } \\
\text { Textbook }\end{array}$} & \multicolumn{4}{|c|}{$\begin{array}{c}\text { Ecological Literacy } \\
\text { Component }\end{array}$} & \multirow[t]{2}{*}{$\begin{array}{l}\text { Compar } \\
\text { ison }\end{array}$} \\
\hline & & $\begin{array}{c}\text { Kno } \\
\text { wled } \\
\text { ge }\end{array}$ & $\begin{array}{l}\text { Affec } \\
\text { tive } \\
\text { Tend } \\
\text { ency }\end{array}$ & $\begin{array}{l}\text { Beha } \\
\text { vior }\end{array}$ & $\begin{array}{l}\text { Cogn } \\
\text { itive } \\
\text { Skills }\end{array}$ & \\
\hline \multirow{2}{*}{$\begin{array}{l}\text { Berbahasa } \\
\text { Indonesia } \\
\text { (Book 1) }\end{array}$} & $\mathrm{f}$ & 31 & 10 & 8 & 6 & 55 \\
\hline & $\%$ & 56 & 18 & 15 & 11 & 64.7 \\
\hline \multirow{2}{*}{$\begin{array}{l}\text { Bahasa dan } \\
\text { Sastra Indonesia } \\
\text { (Book 2) }\end{array}$} & $\mathrm{f}$ & 12 & 0 & 3 & 4 & 18 \\
\hline & $\%$ & 67 & 0 & 11 & 22 & 21.2 \\
\hline \multirow{2}{*}{$\begin{array}{l}\text { Cerdas } \\
\text { Berbahasa } \\
\text { Indonesia } \\
\text { (Book 3) }\end{array}$} & f & 11 & 0 & 0 & 1 & 12 \\
\hline & $\%$ & 92 & 0 & 0 & 8 & 14.1 \\
\hline \multirow{2}{*}{ Total } & $\mathrm{f}$ & 54 & 10 & 10 & 11 & 85 \\
\hline & $\%$ & 63,5 & 11.7 & 11.7 & 12.9 & 100 \\
\hline
\end{tabular}

From table 1, it can be seen that the ecological literacy contained in book 1 includes four components, namely (1) knowledge, (2) affective tendency, (3) behavior, and (4) cognitive skills. Knowledge is the most dominant component compared to the other three components. Of the 55 ecological literacy data contained in book 1, 31 data (56\%) were in the form of knowledge. Meanwhile, the other components were affective tendency (18\%); behavior (15\%), and cognitive skills (11\%).

It can be analyzed further that the elements of knowledge contained in book 1 include (1) ecological knowledge, namely general knowledge about environmental concepts and knowledge and understanding of how the natural system works and the relationship of natural systems with social systems; (2) social-politic knowledge, which is an understanding of a belief, political system, and ecological values of various cultures and an understanding of human cultural activities that influence the environment; and (3) knowledge of environmental issue, namely an understanding of environmental problems derived from the interaction between humans and knowledge related to alternative solutions to environmental problems.

The affective tendency component refers to factors within an individual that allow them to reflect on interpersonal environmental issues, the ability to understand themselves and act according to that understanding in assessing environmental issues and being able to guarantee their own actions. The behavior component contained in book 1 refers to additional determinants that are used as a measure in terms of additional determinants of environmentally responsible behavior and has not yet reached environmentally responsible behavior in solving environmental problems. Meanwhile, cognitive skills refer to analyzing skills, synthesizing, evaluating environmental issues based on evidence and personal values. This category includes the capabilities needed in terms of choosing the right action strategy, evaluating, and implementing planning.

In the second book, only 18 ecological literacy data were found, consisting of 12 data of knowledge (67\%) and containing three components, namely 2 data of behavior (11\%), and 4 data of cognitive skills (22\%). Meanwhile, the affective tendency component was not found. The relevant study also shows that the inclusion level of affective tendency towards environment component of environmental literacy is the least percentage [10].

Book 3 contains the least ecological literacy compared to the other two books. In this book, 12 data were found, consisting of 11 data of knowledge $(92 \%)$ and 1 data of cognitive skills components (8\%); while the affective tendency and behavior component were not found. The component of knowledge consists only of ecological knowledge and knowledge of environmental issue.

Overall, it can be argued that there is a few content of ecological literacy in the three books because it is only 85 data found. Meanwhile, from the inter-component comparison, it is evident that the component of knowledge is the most component $(63.5 \%)$. Meanwhile, the other components are affective tendency $(11.7 \%)$, behavior $(11.7 \%)$, and cognitive skills $(12.9 \%)$. The literacy component is mostly found in the text; and there are a few content of exercise, assignments, or questions. Compared with a similar study, it is found that the inclusion level of knowledge component of environmental literacy is $88.09 \%$ while the inclusion level of cognitive skill component is $2.13 \%$, the inclusion level of affective tendency component is $4.36 \%$ and the inclusion level of behavior is $5.42 \%$ [10]. It can be concluded that, the inclusion level of knowledge component is still dominant in a textbook. However, knowledge is not enough for the protection and the improvement of the environment as well as to improve environmental literacy. In environmental education, not only just cognitive processes but also affective and psychomotor processes should be employed [10].

Environmental education main goal is to improve environmental literacy. It is in line with some researchers who have defined environmental literacy as one of the main goals of environmental education [14]. Despite the great diversity of environmental education programs around the world, there is a common feature among all of them, a lack of evaluation of their effectiveness in achieving their goals: promoting more knowledge, better attitude and a higher prevalence of proenvironmental behavior [15].

A statement in Tbilisi Declaration demonstrates this aim of environmental education: A basic aim of environmental education is to succeed in making individuals and communities understand the complex nature of the natural and built environments and acquire the knowledge, values, attitudes, and practical skills to participate in a responsible and effective way in anticipating and solving environmental 
problems [14]. Therefore, it is necessary to add activities related to ecological literacy in the textbooks because it is suggested on a study that environmental courses should also be adapted and suited to the various kinds of students [14]. In addition, it is thought that it will be useful to create an environmental knowledge content that have all the components of environmental literacy (knowledge-affectbehavior-skill) [10].

\section{CONCLUSION}

There is a few inclusion level of ecological literacy component in Indonesian language textbooks that are compiled based on the Education Unit Level Curriculum for Senior High School. The lack of ecological literacy is dominated by aspects of knowledge, and the least component are related to affective tendency, behavior, and cognitive skills. The component of ecological literacy is generally found in the text. Although the inclusion level of knowledge component is still dominant, however, knowledge is not enough for the protection and the improvement of the environment as well as to improve environmental literacy. Therefore, it is necessary for the government to include all the components of environmental literacy in the textbook.

\section{Acknowledgment}

We thank Ministry of Research, Technology, and Higher Education for the support of funding for this research. In addition, we thank all the boards of the five senior high schools from several cities in Central Java Island that have authorized and cooperated with the present study.

\section{References}

[1] Alikodra, H. S, Conservation of natural and environmental resources: an ecosophy approach to saving the earth (Konservasi sumber daya alam dan lingkungann pendekatan ecosophy bagi penyelamatan bumi), Yogyakarta: Gadjah Mada University Press, 2012, p. xi.

[2] Korten, D. C, Getting to the 21st Century: Voluntary Action and the Global Agenda, Connectticut: Kumarian Press Inc, 1990.
[3] Wills, Jane, A Framework for task-based learning, England: Longman, 1996, p. 12.

[4] Widdowson, H.G, The teaching of english as communication. The communicative approach to language teaching, (ed) C.J. Brumfit dan K. Johnson, Oxford: Oxford University Press, 1987, p. 36.

[5] Cunningsworth, Alan, Choosing your coursbook, Oxford: Heinemann, 1995, p. 7.

[6] Capra, Fritjof, The web of life: A new scientific understanding of living systems. London: Flamingo, 1997, p. 297.

[7] Roth, C. E, Environmental Literacy: Its roots, evolution, and directions in the1990s.Columbus, OH: ERIC Clearinghouse for Science, Mathematics, and Environmental Education, 1992, p. 1.

[8] Dusan, Krnel, and Stanka Naglič, Environmental literacy comparison between eco-schools and ordinary schools in Slovenia, Science Education International Vol.20, No.1/2, December 2009, pp. 5-24.

[9] H. Spinola, Environmental literacy comparison between students taught in Eco-schools and ordinary schools in the Madeira Island region of Portugal, Science Education International, Vol. 26, Issue 3, 2015, pp. 392-413.

[10] Kadir Karatekina. Environmental literacy in Turkey primary schools social studies textbooks, Procedia Social and Behavioral Sciences 46, 2012, pp. 3519-3523.

[11] Kondracki, N. L., Wellman, N. S., \& Amundson, D. R., Content analysis: Review of methods and their applications in nutrition education. Journal of Nutrition Education and Behavior, 34, pp. 224-230.

[12] Creswell, J. W., Controversies in mixed methods research. In N. K. Denzin \& Y. S. Lincoln (Eds.), The sage handbook of qualitative research (4th ed.), Los Angeles, CA: Sage, 2011, pp. 269-284.

[13] Hanson, W. E., Creswell, J. W., Plano Clark, V. L., Petska, K. S., and Creswell, J. D., Mixed methods research designs in counseling psychology, Journal of Counseling Psychology, 52, 2005, pp. 224-235.

[14] Sara Arnona, Nir Orionb, and Nurit Carmia. Environmental literacy components and their promotion by institutions of higher education: an Israeli case study, Environmental Education Research, Vol. 21, No. 7, 2015, pp. 1029-1055.

[15] Disinger, J.F. and Roth, C.E. Environmental Education research news, The Environmentalist, 12: 1992, pp. 165168. 